\title{
Pelayanan Imunisasi Dasar pada Bayi di Bawah Usia 12 Bulan dan Faktor yang Memengaruhi di RSUD Wangaya Kota Denpasar Selama Masa Pandemi COVID-19
}

Fabiola Vania Felicia, I Kadek Suarca

SMF Ilmu Kesehatan Anak RSUD Wangaya Kota Denpasar, Bali

Latar belakang. Pandemi Coronavirus disease 2019 (COVID-19) merupakan kegawatan internasional di bidang kesehatan masyarakat yang membebani sistem kesehatan dan mengganggu kelangsungan layanan kesehatan rutin termasuk imunisasi dasar. Akibatnya, jumlah anak yang diimunisasi menurun, berisiko terjangkit penyakit yang dapat dicegah dengan imunisasi, dan terjadi kejadian luar biasa di tengah pandemi.

Tujuan. Mengetahui kondisi layanan imunisasi dasar pada bayi $<12$ bulan selama masa pandemi COVID-19 dan faktor yang memengaruhi.

Metode. Studi potong lintang ini melibatkan bayi $<12$ bulan yang mendapat imunisasi dasar di Poliklinik Anak RSUD Wangaya pada Januari-Juli 2019 dan 2020. Data diperoleh dari buku registrasi imunisasi poliklinik anak.

Hasil. Kunjungan imunisasi dasar pada Januari-Juli 2020 dan 2019 adalah 123 dan 368 pasien. Dibandingkan dengan kunjungan keseluruhan poliklinik anak, persentasenya $13,1 \%$ dan 21,9\% ( $<<0,001)$. Tren kunjungan per bulan berbeda bermakna pada Mei $(\mathrm{p}<0,001)$, Juni $(\mathrm{p}=0,026)$, dan Juli $(\mathrm{p}=0,036)$. Terjadi penurunan kunjungan pasien sehat, sedangkan pasien dengan kelainan penyerta (bayi dari ibu HIV/AIDS, berat badan lahir rendah, dst) relatif tetap $(\mathrm{p}<0,001)$.

Kesimpulan. Masa pandemi COVID-19 memengaruhi pelayanan imunisasi dasar di rumah sakit berupa penurunan jumlah kunjungan dibandingkan tahun sebelumnya periode yang sama. Faktor yang berpengaruh adalah alasan kunjungan pasien imunisasi. Sari Pediatri 2020;22(3):139-45

Kata kunci: imunisasi dasar, anak, COVID-19, SARS-CoV-2, vaksinasi

\section{Infants' Routine Immunization Services and Associated Factors During COVID-19 Pandemic in Wangaya Regional General Hospital}

Fabiola Vania Felicia, I Kadek Suarca

Background. Coronavirus Disease 2019 (COVID-19) pandemic is an international public health emergency that cause burden on health system and disruption to essential health services including routine childhood immunization. The number of children vaccinated will decrease, put them at risk of vaccine-preventable diseases (VPDs), and raised the likelihood of VPDs outbreak.

Objective. To assess the impact of COVID-19 pandemic on infants' $(<12$ months) routine immunization services and factors associated with it.

Methods. This cross sectional study included all infants' immunization visits at Wangaya Regional General Hospital from January to July 2019 and 2020. Data were collected from pediatric immunization registry book.

Result. 491 infants, 123 in 2019 and 368 in 2020, were enrolled. Percentages of routine immunization visits compared with all pediatric visits in 2020 and 2019 were $13,1 \%$ and $21,9 \%(\mathrm{p}<0,001)$. Based on monthly visits, we found significant differences in May $(p<0,001)$, June $(p=0,026)$, dan July $(p=0,036)$. Healthy infants' immunization visits were markedly decreased, but number of infants with certain conditions (infants born to HIV positive mothers, low birth weight, etc) was similar $(\mathrm{p}<0,001)$.

Conclusion. COVID-19 pandemic has decreased routine immunization visits within 6 months period as well as monthly visits. Infants' related conditions was the sole associating factor. Sari Pediatri 2020;22(3):139-45

Keywords: childhood immunization, vaccination, COVID-19, SARS-CoV-2, pediatric

Alamat korespondensi: Fabiola Vania Felicia SMF Ilmu Kesehatan Anak RSUD Wangaya Kota Denpasar Gedung B Lantai 2, Jl. Kartini No. 133, Denpasar Utara, Bali 80231. Email: fabie2289@gmail.com. 
I munisasi adalah sebuah pelayanan kesehatan yang bertujuan untuk melindungi individu dari penyakit yang dapat dicegah dengan imunisasi (PD3I). ${ }^{1-3}$ Imunisasi merupakan komponen penting dalam pelayanan kesehatan primer dan berperan besar dalam menurunkan angka kematian balita. Imunisasi sudah terbukti sebagai upaya kesehatan yang efisien dan efektif dalam mencegah dan mengurangi angka kesakitan, kecacatan, dan kematian akibat PD3I. Beberapa penyakit tersebut, di antaranya tuberkulosis (TBC), polio, difteri, tetanus, hepatitis B, pertussis, campak, rubella, pneumonia dan meningitis. ${ }^{2,4,5}$ Di Indonesia, setiap bayi (usia di bawah 12 bulan) wajib mendapatkan imunisasi dasar lengkap yang terdiri dari Hepatitis B 1 dosis, Bacillus Calmette-Guerin (BCG) 1 dosis, difteri/pertusis/ tetanus-hepatitis B-Haemophilus influenzae tipe B (DPT-HB-HiB) 3 dosis, oral poliovirus vaccine (OPV) 4 dosis, dan campak/measles-rubella (MR) 1 dosis. ${ }^{2,6}$ Cakupan imunisasi dasar lengkap di Indonesia pada tahun 2018 sebesar 90,61\%, masih sedikit di bawah target Renstra tahun 2018 sebesar 92,5\%. ${ }^{2}$

Saat ini, seluruh dunia sedang menghadapai wabah Coronavirus infection disease 2019 (COVID-19) yang merupakan penyakit infeksi baru disebabkan oleh severe acute respiratory syndrome coronavirus 2 (SARSCoV-2). Penyakit ini pertama kali dilaporkan dan mewabah di Wuhan, Hubei, Cina pada akhir Desember 2019. Pada 11 Maret 2020, badan kesehatan dunia WHO menetapkan COVID-19 sebagai pandemi. ${ }^{7,8}$ Kasus pertama COVID-19 yang terkonfirmasi di Indonesia diumumkan pada tanggal 2 Maret 2020. Hingga bulan Juli 2020, tercatat lebih kurang 68 ribu kasus COVID-19 yang terkonfirmasi dan 3359 kasus kematian. ${ }^{9}$

Di tengah pandemi COVID-19, pelayanan kesehatan terbebani, terfokus pada pencegahan transmisi serta penanganan kasus COVID-19, ditambah penerapan sistem "lockdown", menyebabkan pelayanan kesehatan rutin seperti imunisasi menjadi terganggu. Di Indonesia, dampak COVID-19 terhadap program imunisasi sudah terlihat dari penurunan cakupan vaksinasi beberapa PD3I sebesar $10-40 \%$ pada bulan Maret-April 2020 dibandingkan dengan bulan MaretApril $2019 .{ }^{10} \mathrm{Hal}$ ini dapat menyebabkan krisis kesehatan tambahan (kejadian luar biasa/KLB PD3I) yang berakibat pada peningkatan morbiditas dan mortalitas, dan beban negara. ${ }^{11-14}$ Oleh karena itu, perlu diketahui dampak pandemi COVID-19 terhadap pelayanan imunisasi dasar dan faktor yang memengaruhinya agar dapat disusun rencana yang efektif untuk mencegah penurunan dan mempertahankan kunjungan layanan imunisasi yang, serta menghindari terjadinya KLB akibat PD3I.

\section{Metode}

Penelitian ini menggunakan rancangan penelitian potong lintang. Penelitian dilaksanakan di ruang Poliklinik Anak Rumah Sakit Umum Daerah (RSUD) Wangaya Kota Denpasar pada bulan Agustus 2020. Data sampel diambil dari buku registrasi imunisasi di Poliklinik Anak RSUD Wangaya Kota Denpasar periode Januari 2019 hingga Juli 2019 dan Januari 2020 hingga Juli 2020. Yang termasuk sampel dalam penelitian ini adalah semua bayi usia $<12$ bulan yang mendapatkan layanan imunisasi dasar. Data sampel yang tidak lengkap pada buku registrasi imunisasi tidak diikusertakan dalam penelitian. Penelitian ini telah dinyatakan layak etik oleh Komite Etik Penelitian Kesehatan RSUD Wangaya Kota Denpasar, Bali.

Data dikumpulkan dan dicatat di Microsoft Excel yang meliputi tanggal kunjungan, identitas, usia, jenis kelamin, jenis imunisasi dasar, penyakit penyerta, dan asal rujukan. Setelah itu data dimasukkan ke dalam program SPSS 23.0 dan dilakukan analisis dengan uji Chi square atau bila syarat Chi square tidak terpenuhi menggunakan uji Fisher. Selanjutnya data dengan variabel polikotom dilakukan analisis multivariat menggunakan regresi logistik. Hasil penelitian dinyatakan bermakna apabila nilai $\mathrm{p}<0,05$.

\section{Hasil}

Penelitian ini melibatkan seluruh bayi di bawah usia 12 bulan yang mendapatkan imunisasi dasar di Poliklinik Anak RSUD Wangaya Kota Denpasar pada bulan Januari 2019 - Juli 2019 dan Januari 2020 - Juli 2020 yang memenuhi kriteria inklusi dan eksklusi (Tabel 1). Total kunjungan imunisasi berjumlah 491 pasien. Secara keseluruhan, total kunjungan poliklinik anak periode Januari- Juli tahun 2020 adalah 939 pasien dan Januari-Juli 2019 adalah 1682 pasien. Persentase kunjungan imunisasi dibandingkan dengan kunjungan keseluruhan poliklinik anak pada tahun 2020 adalah 13,1\% (123/939), sedangkan tahun 2019 adalah 
Fabiola Vania Felicia dkk: Pelayanan imunisasi dasar pada bayi di bawah usia 12 bulan dan faktor yang memengaruhi selama masa pandemi COVID-19

21,9\% (368/1682). Bila dilihat berdasarkan bulan, jumlah total kunjungan per bulan tahun 2020 dan tahun 2019 berturut-turut adalah Januari 102 (20,8\%), Februari 55 (11,2\%), Maret 81 (16,5\%), April 65 (13,2\%), Mei 59 (12\%), Juni 74 (15,1\%), dan Juli 55 (11,2\%).

Median usia bayi yang melakukan kunjungan imunisasi dasar adalah 2 bulan (0-11 bulan). Berdasarkan jenis kelamin, jumlah pasien laki-laki dan perempuan hampir sama berturut-turut 255 (51,9\%) dan 236 (48,1\%). Keseluruhan pelayanan imunisasi dasar yang diberikan adalah 889 vaksin, 663 (74,6\%) vaksin di tahun 2019 dan 226 (25,4\%) vaksin di tahun 2020. Pemberian imunisasi dasar meliputi hepatitis B0 $28(3,1 \%)$, BCG $223(25,1 \%)$, polio $395(44,4 \%)$, DPT-HB-Hib 197 (22,2\%), dan campak 46 (5,2\%). Dari 360 pasien yang mendapatkan vaksin polio, 350 pasien diberikan OPV dan 10 pasien inactivated polio vaccine/IPV. Pasien yang mendapatkan imunisasi dasar sebagian besar sehat (tanpa penyakit penyerta) $354(72,1 \%)$ dan lainnya adalah pasien sehat dengan penyakit penyerta (bayi dari ibu HIV/AIDS positif (BIHA), bayi berat badan lahir rendah (BBLR), dst) $137(27,9 \%)$.

Bila melihat jumlah kunjungan layanan imunisasi dasar pada masing-masing bulan, tampak menurun signifikan di tahun 2020 dibandingkan tahun 2019. Sementara secara statistik didapatkan perbedaan signifikan (Tabel 2). Perbedaan ini dipengaruhi oleh banyak faktor. Untuk mengetahui faktor yang memengaruhi perbedaan ini, berdasarkan data yang ada pada buku registrasi imunisasi, didapatkan hasil seperti tertera pada Tabel 3 .

Tidak ditemukan hubungan antara jenis kelamin dan status rujukan pasien dengan layanan imunisasi dasar $(p>0,05)$. Namun, ditemukan hubungan antara
Tabel 1. Karakteristik sampel penelitian

\begin{tabular}{lcc}
\hline Karakteristik & $\begin{array}{c}\text { Tahun 2020 } \\
(\mathrm{n}=123)\end{array}$ & $\begin{array}{c}\text { Tahun 2019 } \\
(\mathrm{n}=368)\end{array}$ \\
\hline $\begin{array}{l}\text { Usia (bulan), median (min- } \\
\text { maks) }\end{array}$ & $2(0-11)$ & $2(0-11)$ \\
\hline $\begin{array}{l}\text { Jenis kelamin, n (\%) } \\
\text { Laki-laki }\end{array}$ & $69(56,1)$ & $186(50,5)$ \\
$\quad$ Perempuan & $54(43,9)$ & $182(49,5)$ \\
Alasan kunjungan, n (\%) & & \\
$\quad$ Sehat & $69(56,1)$ & $285(77,4)$ \\
$\quad$ Sehat dengan penyakit & $54(43,9)$ & $83(22,6)$ \\
penyerta & & \\
Rujukan, n (\%) & & \\
$\quad$ Tidak & $117(95,1)$ & $349(94,8)$ \\
$\quad$ Ya & $6(4,9)$ & $19(5,2)$ \\
Bulan, n (\%) & & \\
Januari & $35(28,5)$ & $67(18,2)$ \\
Februari & $23(18,7)$ & $32(8,7)$ \\
Maret & $23(18,7)$ & $58(15,8)$ \\
April & $14(11,4)$ & $51(13,9)$ \\
Mei & $4(3,3)$ & $55(14,9)$ \\
Juni & $14(11,4)$ & $60(16,3)$ \\
Juli & $10(8,1)$ & $45(12,2)$ \\
\hline
\end{tabular}

Tabel 2. Perbedaan pelayanan imunisasi dasar per bulan

\begin{tabular}{lccl}
\hline & \multicolumn{2}{c}{ Tahun } & \multirow{2}{*}{ Nilai p } \\
\cline { 2 - 3 } & 2020 & 2019 & \\
\cline { 2 - 3 } $\begin{array}{l}\text { Kunjungan per } \\
\text { bulan, n (\%) }\end{array}$ & & & $<0,001$ \\
$\quad$ Januari & $35(34,3)$ & $67(65,7)$ & \\
Februari & $23(41,8)$ & $32(58,2)$ & \\
Maret & $23(28,4)$ & $58(71,6)$ & \\
April & $14(21,5)$ & $51(78,5)$ & \\
Mei & $4(6,8)$ & $55(93,2)$ & \\
Juni & $14(18,9)$ & $60(81,1)$ & \\
Juli & $10(18,2)$ & $45(81,8)$ & \\
\hline
\end{tabular}

Tabel 3. Faktor-faktor yang memengaruhi layanan imunisasi dasar

\begin{tabular}{|c|c|c|c|c|c|}
\hline & \multicolumn{2}{|c|}{ Tahun } & \multirow{2}{*}{ Nilai p } & \multirow{2}{*}{ OR (IK95\%) } \\
\hline & & 2020 & 2019 & & \\
\hline \multirow{2}{*}{ Jenis kelamin } & Laki-laki & $69(27,1)$ & $186(72,9)$ & 0,335 & $1,25(0,83-1,88)$ \\
\hline & Perempuan & $54(22,9)$ & $182(77,1)$ & & \\
\hline \multirow[t]{2}{*}{ Alasan kunjungan } & Sehat & $69(19,5)$ & $285(80,5)$ & $<0,001$ & $2,69(1,74-4,14)$ \\
\hline & Sehat dengan penyakit penyerta & $54(39,4)$ & $83(60,6)$ & & \\
\hline \multirow[t]{2}{*}{ Rujukan } & Tidak & $117(25,1)$ & $349(74,9)$ & 1,000 & $1,06(0,41-2,72)$ \\
\hline & Ya & $6(24)$ & $19(76)$ & & \\
\hline
\end{tabular}

Keterangan: OR = Odds ratio; IK = Interval Kepercayaan 
penyakit penyerta pasien dengan layanan imunisasi dasar (hasil uji Chi square tabel $2 x k \mathrm{p}<0,001$ ). Karena hanya satu variabel yang memiliki nilai $\mathrm{p}<0,25$, tidak dilakukan analisis multivariat terhadap faktor tersebut.

Analisis regresi logistik sederhana digunakan untuk mengetahui seberapa besar perbedaan layanan imunisasi dasar per bulan. Berdasarkan bulan kunjungan layanan imunisasi dasar, dengan bulan Januari sebagai pembanding, tidak terdapat perbedaan jumlah kunjungan bulan Februari-April ( $p>0,05)$. Perbedaan jumlah kunjungan terlihat pada bulan Mei-Juli $(\mathrm{p}<0,05)$ dengan interval kepercayaan (IK) 95\% tidak melewati angka 1 . Perbedaan kunjungan pada bulan Mei adalah 7,2 kali lebih besar daripada bulan Januari (OR: 7,18; IK95\% 2,41-21,45); perbedaan kunjungan pada bulan Juni 2,2 kali lebih besar dibandingkan bulan Januari (OR: 2,24; IK95\% 1,10-4,56); dan perbedaan kunjungan pada bulan Juli 2,3 kali lebih besar dibandingkan bulan Januari (OR: 2,35; IK95\% 1,06-5,22).

\section{Pembahasan}

Pandemi COVID-19 menyebabkan dunia menghadapi tantangan baru dalam sistem kesehatan. Banyak negara mengalihkan pelayanan kesehatan untuk penanganan kasus COVID-19 yang tinggi sehingga menambah beban sistem kesehatan. Begitupun faktor ketakutan masyarakat dengan adanya pandemi menyebabkan pelayanan kesehatan lain yang rutin terganggu. Hal ini disebabkan penyampaian informasi kepada masyarakat yang kurang dan juga jumlah penyedia layanan kesehatan yang terbatas..$^{11,14,15}$

Pelayanan imunisasi sebagai salah satu bentuk layanan kesehatan rutin dasar yang penting menjadi terhambat dengan adanya pandemi ini. Jutaan anak di dunia, baik negara maju maupun negara berkembang, berisiko terhadap PD3I, seperti difteri, campak, polio dan pneumonia, yang sebelumnya sudah terkontrol dengan adanya imunisasi. ${ }^{16}$

Pada penelitian ini, dengan menggunakan data yang tersedia dalam buku registrasi imunisasi di poliklinik anak, didapatkan perbedaan bermakna secara statistik jumlah kunjungan layanan imunisasi dasar pada bulan Januari 2020 -Juli 2020 dan Januari 2019 -Juli 2019. Bila dibandingkan, terjadi penurunan pelayanan imunisasi dasar secara keseluruhan maupun pada masing-masing bulannya. Dari perbedaan kunjungan imunisasi tiap bulan ini, dengan bulan Januari sebagai pembanding, ditemukan bahwa perbedaan bermakna tampak pada bulan Mei-Juli berupa penurunan kunjungan imunisasi dasar.

Kasus pertama COVID-19 yang terkonfirmasi di Bali diumumkan pada tanggal 11 Maret $2020 .{ }^{17}$ Seiring dengan bertambahnya jumlah kasus COVID-19, pemerintah setempat menghimbau masyarakat untuk mengurangi aktivitas di luar rumah. Penerapan Pembatasan Kegiatan Masyarakat (PKM) dimulai pada tanggal 15 Mei 2020. Masyarakat wajib menggunakan masker dan menerapkan perilaku hidup sehat (PHBS), social distancing dan physical distancing tetap dijalankan. ${ }^{18}$ Himbauan dalam rangka mencegah penyebaran COVID-19 dengan melakukan aktivitas dari rumah atau berdiam di rumah dan pembatasan kegiatan masyarakat di luar rumah memengaruhi akses dan pembatasan aktivitas pelayanan kesehatan di fasilitas kesehatan. Ditambah penerapan PKM yang dimulai di kota Denpasar pada pertengahan bulan Mei 2020. Hal tersebut menyebabkan penurunan kunjungan layanan imunisasi dasar pada bulan Mei hingga Juli 2020 semakin bermakna dibandingkan dengan bulan sebelumnya.

Dampak COVID-19 terhadap program imunisasi di Indonesia dipaparkan dalam WHO Indonesia Situation Report-13, yaitu bahwa terjadi penurunan cakupan vaksinasi beberapa penyakit yang dapat dicegah dengan imunisasi sebesar $10-40 \%$ pada Maret-April 2020 dibandingkan dengan Maret-April 2019. Hal ini terjadi karena tenaga kesehatan (petugas imunisasi) dialihkan untuk penanganan COVID-19. Petugas vaksinasi pun khawatir terhadap risiko transmisi COVID-19 yang dapat terjadi saat pelayanan imunisasi. Disamping itu, penerapan Pembatasan Sosial Skala Besar (PSBB) di banyak daerah menyebabkan aktivitas di luar rumah dibatasi dan sulitnya akses/transportasi ke pelayanan kesehatan. ${ }^{19}$ Direktur Surveilans dan Karantina Kesehatan, Kemenkes RI, menjelaskan bahwa hampir 83,9\% layanan kesehatan, khususnya program imunisasi terhenti akibat pandemi. ${ }^{20}$ Terhambatnya pelaksanaan imunisasi di Indonesia saat masa pandemi COVID-19 ini mendasari terbitnya "Petunjuk Teknis Pelayanan Imunisasi Pada Masa Pandemi COVID-19" oleh Direktorat Surveilans dan Karantina Kesehatan Direktorat Jenderal Pencegahan dan Pengendalian Penyakit (P2P) Kementerian Kesehatan (Kemenkes). ${ }^{21}$

Lockdown di Karachi, Pakistan, akibat pandemi COVID-19 juga berdampak pada pelayanan imunisasi 
Fabiola Vania Felicia dkk: Pelayanan imunisasi dasar pada bayi di bawah usia 12 bulan dan faktor yang memengaruhi selama masa pandemi COVID-19

rutin. Chandir $\mathrm{dkk}^{12}$ membandingkan data imunisasi rutin Karachi dari electronic immunization registry provinsi 6 bulan sebelum lockdown COVID-19 dengan data selama 6 minggu masa lockdown. Dari total 701.324 data, 608.832 anak (usia 0-23 bulan) mendapatkan imunisasi dalam 6 bulan sebelum lockdown dan hanya 92.492 anak yang diimunisasi selama masa lockdown. Terjadi penurunan 52,8\% jumlah kunjungan imunisasi perharinya (dari 5184 menjadi 2450 kunjungan) selama masa lockdown dibadingkan sebelumnya.

Efek pandemi COVID-19 terhadap imunisasi rutin pada anak di Amerika Serikat tampak dari penurunan jumlah pemesanan vaccines for children program (VFC) oleh fasilitas kesehatan. Santoli $\mathrm{dkk}^{13}$ membandingkan jumlah kumulatif pemesanan VFC per minggu pada 2 periode, yaitu Januari-April 2019 (periode 1) dan Januari-April 2020 (periode 2), yang dibagi menjadi vaksin non influenza dan campak. Penurunan pemesanan VFC mulai tampak seminggu setelah COVID-19 diumumkan sebagai kondisi kegawatan nasional (13 Maret 2020). Penurunan ini segera ditanggapi dan ditangani dengan strategi mempromosikan kegiatan vaksinasi anak dalam konteks pandemi, menjangkau pasien yang sudah terlewat jadwal imunisasi, serta pengaturan alur vaksinasi untuk meminimalisir kontak antar pasien. Pada akhir Maret, pemberian vaksin pada anak mulai mengalami peningkatan. ${ }^{13}$ Data vaksin yang diambil oleh PCC (Pyhsician's Computer Company), sebuah perusahaan pediatric electronic health records, dari 1000 spesialis anak di Amerika Serikat ditemukan penurunan vaksin MMR (measles, mumps and rubella) sebesar $50 \%$ dan vaksin difteria dan pertusis $42 \%$ pada periode 5 April dibandingkan periode 16 Februari. ${ }^{22}$ Para ahli memperkirakan penurunan cakupan imunisasi ini hampir mencapai $73 \%$ yang berarti sekitar 3 dari 4 anak yang terjadwal untuk imunisasi tidak mendapatkannya. ${ }^{23}$

Di Afrika, dampak akibat terhambatnya layanan imunisasi rutin sudah terbukti dengan KLB PD3I yang terjadi saat Afrika Barat mengalami wabah Ebola di tahun 2013-2016. Di masa pandemi COVID-19, Abbas $\mathrm{dkk}^{24}$ dengan studi analisis sensitivitas probabilistik menemukan bahwa keuntungan dalam pelaksanaan imunisasi rutin pada anak di Afrika jauh lebih besar dibandingkan risiko kematian akibat COVID-19 yang berisiko didapat saat kunjungan vaksinasi. Gambaran dampak besar, untuk setiap 1 kasus kematian akibat COVID-19 yang didapat saat kunjungan imunisasi, 84 (95\%Uncertainity Intervals/UI 14-267) kematian anak dapat dicegah dengan pelaksanaan imunisasi rutin di Afrika.

Banyak faktor yang memengaruhi jumlah kunjungan layanan imunisasi selama masa pandemi. Dalam penelitian ini ditemukan hubungan antara penyakit penyerta pasien dengan kunjungan layanan imunisasi selama masa pandemi COVID-19, tetapi tidak pada jenis kelamin dan status rujukan pasien. Mayoritas pasien tidak dirujuk (datang sendiri) dan dengan biaya pribadi. Status BIHA berhubungan dengan kunjungan imunisasi bila dibandingkan dengan pasien sehat. Hubungan ini ditunjukkan dari penurunan jumlah kunjung pasien sehat (tanpa penyakit penyerta), sedangkan jumlah kunjungan pasien dengan penyakit penyerta relatif sama. Hal ini mungkin dikarenakan pasien dengan status BIHA dan kondisi khusus lainnya memang harus mendapatkan imunisasi di rumah sakit oleh dokter spesialis anak sehingga kecenderungan untuk tetap datang lebih tinggi. Pasien sehat dapat meneruskan layanan imunisasi di fasilitas kesehatan primer atau lainnya yang lebih dekat dari tempat tinggal, disamping itu juga kemungkinan orang tua cenderung lebih khawatir untuk membawa anak sehat ke rumah sakit.

Bayi yang lahir dari ibu dengan HIV/ADS tetap perlu diberikan imunisasi sesuai jadwal imunisasi nasional, termasuk imunisasi BCG. Imunisasi BCG tidak diberikan pada anak dengan infeksi HIV yang telah bergejala. Pemberian imunisasi pada BIHA ini juga dianjurkan dilakukan dengan berkonsultasi dengan dokter spesialis anak. ${ }^{25,26}$

Sebagai respon terhadap pandemi COVID-19, banyak negara yang melakukan lockdown dengan pemberlakukan physical-social distancing yang ketat, isolasi, dan karantina. Lockdown kemungkinan akan menurunkan transmisi banyak PD3I dalam masyarakat. ${ }^{14} \mathrm{Adamu}^{28}$ menganalisis hubungan antara COVID-19, strategi pencegahannya, dan imunisasi menggunakan sebuah sistem model dinamis, yaitu causal loop diagram (CLD). Melalui model ini ditemukan bahwa hubungan kasus COVID-19 dan lockdown membentuk sebuah keseimbangan. Hal ini berarti dengan peningkatan kasus COVID-19 pemerintah akan memberlakukan lockdown untuk menurunkan transmisi sehingga angka kasus COVID-19 menurun. Jika kasus COVID-19 tetap meningkat, akan terjadi penurunan tenaga kesehatan yang tersedia untuk layanan imunisasi, fasilitas kesehatan dijadikan tempat penanganan/isolasi pasien COVID-19 dan berujung pada penurunan layanan imunisasi. ${ }^{27}$ Secara langsung, 
Fabiola Vania Felicia dkk: Pelayanan imunisasi dasar pada bayi di bawah usia 12 bulan dan faktor yang memengaruhi selama masa pandemi COVID-19

lockdown juga akan memberikan tantangan besar bagi dokter dan penyedia layanan kesehatan dalam pelaksanaan layanan imunisasi. Isolasi mandiri, bayi di keluarga yang terinfeksi COVID-19, gangguan distribusi penyediaan vaksin dan akses ke fasilitas kesehatan karena penutupan jalan serta pembatasan sistem transportasi umum merupakan faktor yang kemungkinan akan secara bermakna memengaruhi penurunan pelaksanaan imunisasi rutin sesuai jadwal. Dampak tidak langsung lockdown terhadap imunisasi berhubungan dengan kondisi ekonomi, khususnya bagi masyarakat yang sumber pendapatannya bergantung pada aktivitas informal. ${ }^{14,27}$

Sebaliknya, yang ditakutkan adalah ketika lockdown berakhir, physical-social distancing dilonggarkan dan sekolah dibuka kembali, maka KLB penyakitpenyakit seperti campak, pertusis, dan gastroenteritis akibat rotavirus tampaknya tidak dapat dihindari. Di United Kingdom (UK), pemberian imunisasi rutin direkomendasikan untuk tetap berjalan sesuai jadwal di praktek dokter umum. Cakupan imunisasi selama masa pandemi juga perlu dipantau pada berbagai tingkatan wilayah agar bila terjadi pernurunan yang tajam bisa segera ditindaklanjuti dan mengantisipasi dampak yang mungkin ditimbulkan. ${ }^{14}$ Rencana untuk kembali pada aktivitas sebelum pandemi "new normal" selain berpatokan dengan upaya pencegahan transmisi COVID-19 juga harus mempertimbangkan kemampuan fasilitas layanan kesehatan untuk menangani bila penyakit endemik lainnya mulai bermunculan. Oleh karena itu, data cakupan imunisasi dari masing-masing fasilitas kesehatan, wilayah (desa, keluarahan, dst) hingga nasional perlu diketahui dan mendukung, sebelum dibuat keputusan untuk melonggarkan PSBB atau pemberlakuan "new normal". Setelah diketahui seberapa besar penurunan pelayanan imunisasi tersebut, diidentifikasikan penyebabnya, baik dari masyarakat, pihak penyedia layanan kesehatan, dan juga manajemen logistik vaksin sehingga dapat disusun strategi untuk meningkatkan kembali cakupan imunisasi dasar pada anak saat pandemi COVID-19 sudah terkontrol.

Penelitian ini memiliki beberapa keterbatasan. Pertama, data dalam penelitian ini diperoleh dari buku registrasi imunisasi di poliklinik anak sehingga komponen data yang dapat dianalisis untuk mencari faktor-faktor yang memengaruhi perbedaan jumlah kunjungan imunisasi pun tidak banyak (terbatas). Karena keterbatasan waktu dalam penelitian ini, tidak dilakukan penyebaran kuesioner yang dapat menambah komponen data lain untuk identifikasi faktor-faktor yang berpengaruh terhadap pelayanan imunisasi. Terakhir, penelitian hanya dilakukan di satu tempat yaitu RSUD tipe B maka data yang diperoleh mungkin tidak dapat digeneralisasikan karena imunisasi dasar merupakan pelayanan kesehatan primer yang dilakukan di fasilitas kesehatan tingkat pertama.

\section{Kesimpulan}

Masa pandemi COVID-19 memengaruhi pelayanan imunisasi dasar di rumah sakit yaitu berupa penurunan (perbedaan) jumlah kunjungan imunisasi dasar ke poliklinik anak dibandingkan dengan tahun sebelumnya pada periode yang sama. Faktor yang memengaruhi perbedaan ini adalah penyakit penyerta pasien imunisasi. Penurunan jumlah kunjungan terlihat pada pasien sehat dan namun tidak pada pasien dengan penyakit penyerta seperti BIHA, BBLR yang jumlah kunjungannya relatif tetap.

\section{Daftar pustaka}

1. World Health Organization and The United Nations International Children's Fund. Immunization in the context of COVID-19 pandemic: Frequently Asked Questions (FAQ). WHO. 16 April 2020. Diakses pada 5 Juli 2020. Didapat dari: https://apps.who.int/iris/handle/10665/331818.

2. Kementerian Kesehatan Republik Indonesia. Profil Kesehatan Indonesia 2018. Pusat Data dan Informasi Kemenkes RI. 2019. Diakses pada 27 Maret 2020. Didapat dari: https:// pusdatin.kemkes.go.id/folder/view/01/structure-publikasipusdatin-profl-kesehatan.html.

3. Kementerian Kesehatan Republik Indonesia. Pedoman penyelenggaraan imunisasi. Kemenkes RI. 2004. Diakses pada 4 Juli 2020. Didapat dari: http://www.pdpersi.co.id/peraturan/ kepmenkes/kmk10592004.pdf.

4. Kementerian Kesehatan Republik Indonesia. Petunjuk teknis pelayanan imunisasi pada masa pandemi COVID-19. Kemenkes RI. 2020. Diakses pada 6 Juli 2020. Didapat dari: https://covid19.kemkes.go.id/protokol-covid-19/petunjukteknis-pelayanan-imunisasi-pada-masa-pandemi-covid-19/\#. Xyoy8CgzbIU.

5. World Health Organization. Immunization Agenda 2030: A global strategy to leave no one behind. 2 April 2020. Diakses pada 7 April 2020. Didapat dari: https://www.who. int/immunization/immunization_agenda_2030/en/. 
Fabiola Vania Felicia dkk: Pelayanan imunisasi dasar pada bayi di bawah usia 12 bulan dan faktor yang memengaruhi selama masa pandemi COVID-19

6. Badan Kependudukan dan Keluarga Berencana Nasional (BKKBN), Badan Pusat Statistik (BPS), Kementerian Kesehatan RI. Survei Demografis dan Kesehatan Indonesia (SDKI) 2017. BKKBN. 2018. Diakses pada 17 Maret 2020. Didapat dari: https://e-koren.bkkbn.go.id/wp-content/ uploads/2018/10/Laporan-SDKI-2017-WUS.pdf.

7. Cui X, Zhang T, Zheng J, dkk. Children with Coronavirus Disease 2019 (COVID-19): A review of demographic, clinical, laboratory and imaging features in pediatric patients. J Med Virol 2020:1-10.

8. World Health Organization (WHO). Coronavirus disease 2019 (COVID-19) Situation Report-51. 11 Maret 2020. Dunduh pada 7 Juli 2020. Didapat dari: https://www.who.int/ docs/default-source/coronaviruse/situation-reports.

9. WHO Indonesia. Coronavirus Disease 2019 (COVID-19) Situation Report-15. 08 Juli 2020. Diakses pada 8 Juli 2020. Didapat dari: https://www.who.int/docs/default-source/searo/ indonesialcovid19/.

10. WHO Indonesia. Coronavirus Disease 2019 (COVID-19) Situation Report-13. 24 Juni 2020. Diakses pada 10 Juli 2020. Didapat dari: https://www.who.int/docs/default-source/ searo/indonesialcovid19.

11. WHO Western Pacific Region. Routine immunization services during the COVID-19 pandemic. 13 April 2020. Diakses pada 5 Juli 2020. Didapat dari: https://apps.who.int/ iris/handle/10665/331925.

12. Chandir S, Siddiqi DA, Setayesh H, Khan AJ. Impact of COVID-19 lockdown on routine immunisation in Karachi, Pakistan [published online ahead of print, 2020 Jun 29]. Lancet Glob Health 2020;8:1118-20.

13. Santoli JM, Lindley MC, DeSilva MB, dkk. Effects of the COVID-19 pandemic on routine pediatric vaccine ordering and administration — United States, 2020. MMWR Morb Mortal Wkly Rep 2020;69:591-3. doi:10.15585/mmwr. mm6919e2.

14. Hungerford D, Cunliffe NA. Coronavirus disease (COVID-19) - impact on vaccine preventable diseases. Euro Surveill 2020; 25:2000756. doi:10.2807/1560-7917.ES.2020.25.18.2000756.

15. World Health Organization. Maintaining Essential Health Services: Operasional guidance for the COVID-19 context. Interim guidance. 1 June 2020. Diakses pada 30 Juli 2020. Didapat dari: https://www.who.int/publications-detail/covid-19operational-guidance-for-maintaining-essential-health-servicesduring-an-outbreak.

16. United Nation News. Experts underscore COVID-19 threat to global progress on child immunization. 22 May 2020. Diakses pada 30 Juli 2020. Didapat dari: https://news.un.org/ en/story/2020/05/1064772.

17. Asmara, CG. Pasien pertama positif corona meninggal di
RSUP Sanglah. CNBC Indonesia 11 March 2020. Diakses pada 30 Juli 2020. Didapat dari: https://www.cnbcindonesia. com/news/20200311155633-4-144129/pasien-pertama-positifcorona-meninggal-di-rsup-sanglah-bali.

18. Rosidin I, Agriesta D. Pembatasan Kegiatan Masyarakat (PKM) di Denpasar mulai berlaku 15 Mei 2020. Denpasar. Kompas. com 13 May 2020. Diakses pada 30 Juli 2020. Didapat dari: https://denpasar.kompas.com/read/2020/05/13/21000751/ pembatasan-kegiatan-masyarakat-di-denpasar-mulai-berlaku15-mei-2020?page $=$ all.

19. WHO Indonesia. Coronavirus Disease 2019 (COVID-19) Situation Report-13. 24 Juni 2020. Diakses pada 10 Juli 2020. Didapat dari: https://www.who.int/docs/default-sourcel searo/indonesialcovid19/.

20. Hanasah, A. COVID-19 pandemic affects children's immunization program: Ministry. Antaranews.com 9 June 2020. Diakses pada 31 Juli 2020. Didapat dari: https://voinews. id/index.php/component/k2/item/7599-covid-19-pandemicaffects-children-s-immunization-program-ministry.

21. Sutrisno E. Layanan imunisasi di tengah pandemi. Indonesia. go.id 30 May 2020. Diakses pada 31 Juli 2020. Didapat dari: https://indonesia.go.id/layanan/kesehatan/ekonomi/layananimunisasi-di-tengah-pandemi.

22. Hoffman, J. Vaccine rates drop dangerously as parents avoid doctor's visit. The New York Times 23 April 2020. Diakses pada 31 Juli 2020. Didapat dari: https://www.nytimes. com/2020/04/23/health/coronavirus-measles-vaccines.html.

23. Dunn, J. Your kids still need their vaccines, even during coronavirus crisis. Seattle's Child 18 June 2020. Diakses pada 31 Juli 2020. Didapat dari: https://www.seattleschild.com/yourkids-still-need-their-vaccines-even-during-coronavirus-crisis/.

24. Abbas K, Procter SR, Zandvoort KV, dkk. Routine childhood immunisation during The COVID-19 pandemic in Africa: A benefit-risk analysis of health benefits versus excess risk of SARS-CoV-2 infection. Lancet Glob Health 2020;8: 1264-72.

25. World Health Organization. Anak dengan HIV/AIDS. Dalam: Pedoman bagi rumah sakit rujukan tingkat pertama di kabupaten/kota. Jakarta: WHO Indonesia: 2009. h.238.

26. Kementerian Kesehatan RI. Peraturan Menteri Kesehatan Republik Indonesia tentang eliminasi penularan human immunodeficiency virus (HIV), sifilis, dan hepatitis B dari ibu ke anak. Kemenkes RI. 2017. Diundur pada 1 Agustus 2020. Didapat dari: https://www.persi.or.id/images/regulasi/permenkes/ pmk522017.pdf.

27. Adamu AA, Jalo RI, Haboninama D, dkk. COVID-19 and routine childhood immunization in Africa: Leveraging systems thinking and implementation science to improve immunization system performance. Int J Infect Dis 2020;98:161-5. 